\title{
Evaluation of patients with stroke monitored by home care programs
}

\author{
AVALIAÇÃO DE PACIENTES COM ACIDENTE VASCULAR CEREBRAL ACOMPANHADOS \\ POR PROGRAMAS DE ASSISTÊNCIA DOMICILIÁRIA
}

\section{EVALUACIÓN DE PACIENTES CON ACCIDENTE CEREBROVASCULAR ACOMPAÑADOS POR PROGRAMAS DE CUIDADO DOMICILIARIO}

\section{Ana Railka de Souza Oliveira1, Thelma Leite de Araujo², Alice Gabrielle de Sousa Costa ${ }^{3}$, Huana Carolina Cândido Morais ${ }^{4}$, Viviane Martins da Silva ${ }^{5}$, Marcos Venícios de Oliveira Lopes ${ }^{6}$}

\begin{abstract}
The purpose of this study was to evaluate the patient with a stroke in home treatment, investigating physical capacity, mental status and anthropometric analysis. This was a cross-sectional study conducted in Fortaleza/CE, from January to April of 2010. Sixty-one individuals monitored by a home care program of three tertiary hospitals were investigated, through interviews and the application of scales. The majority of individuals encountered were female (59\%), elderly, bedridden, with a low educational level, a history of other stroke, a high degree of dependence for basic (73.8\%) and instrumental (80.3\%) activities of daily living, and a low cognitive level (95.1\%). Individuals also presented with tracheostomy, gastric feeding and urinary catheter, difficulty hearing, speaking, chewing, swallowing, and those making daily use of various medications. It was concluded that home care by nurses is an alternative for care of those individuals with a stroke.
\end{abstract}

\section{DESCRIPTORS}

Stroke

Home nursing

Nursing care

\section{RESUMO}

A proposta do estudo foi avaliar o paciente com acidente vascular cerebral em tratamento domiciliário, investigando capacidade funcional, estado mental e análise antropométrica. Estudo transversal realizado em Fortaleza/CE, de janeiro a abril de 2010. Foram investigados 61 indivíduos acompanhados pelo programa de assistência domiciliar de três hospitais terciários, mediante entrevista e aplicação de escalas. Encontrou-se maioria do sexo feminino (59\%), idosos, acamados, com baixa escolaridade, com história de outros eventos de acidente vascular cerebral, elevado grau de dependência para as atividades básicas $(73,8 \%$ ) e instrumentais $(80,3 \%)$ da vida diária e baixo nível cognitivo (95,1\%). Também apresentavam traqueostomia, sondagem gástrica e vesical, dificuldades para ouvir, falar, mastigar, engolir e faziam uso diário de vários medicamentos. Concluiu-se que o atendimento domiciliário de enfermagem consolida-se como alternativa de assistência aos indivíduos com acidente vascular cerebral.

\section{DESCRITORES \\ Acidente vascular cerebral \\ Assistência domiciliária \\ Cuidados de enfermagem}

\begin{abstract}
RESUMEN
La propuesta del estudio fue evaluar al paciente con accidente cerebro vascular en tratamiento domiciliario, se investigó la capacidad funcional, el estado mental y el análisis antropométrico. Estudio transversal desarrollado en Fortaleza/CE, de enero a abril del 2010. Se investigaron 61 personas acompañadas por el programa de atención domiciliaria de tres hospitales de nivel terciario a través de entrevistas y aplicación de escalas. Se encontró en la mayoría: mujeres (59\%), adultos mayores, postrados en cama, con bajo nivel de educación, con historia de otros accidentes cerebro vasculares, alto grado de dependencia para las actividades básicas $(73,8 \%)$ e instrumentales $(80,3 \%)$ de la vida diaria y bajo nivel cognitivo (95,1\%). También tenían traqueotomía, sonda nasogástrica y vesical, dificultad para oír, hablar, masticar, tragar y usaban varios medicamentos diarios. Se concluye que la atención domiciliaria de enfermería se consolida como alternativa de cuidado a las personas con accidente cerebro vascular.
\end{abstract}

\section{DESCRIPTORES \\ Accidente cerebrovascular Atención domiciliaria de salud Atención de enfermería.}

\footnotetext{
1 Nurse. Doctoral student, Graduate Program in Nursing, Universidade Federal do Ceará. Fellowship from CAPES. Fortaleza, CE, Brazil. railkaufc@yahoo.com.br ${ }^{2}$ Doctorate in nursing. Full Professor, Department of Nursing, Universidade Federal do Ceará. CNPq Researcher. Fortaleza, CE, Brazil. Thelmaaraujo2012@gmail.com ${ }^{3}$ Nurse. Doctoral student, Graduate Program in Nursing, Universidade Federal do Ceará. Fellowship from FUNCAP. Fortaleza, CE, Brazil. alice gabrielle@yahoo.com.br ${ }^{4}$ Nurse. Doctoral student, Graduate Program in Nursing, Universidade Federal do Ceará. Fortaleza, CE, Brasil. huanacarolina@yahoo.com.br ${ }^{5}$ Doctorate in nursing. Professor, Department of Nursing, Universidade Federal do Ceará. Fortaleza, CE, Brazil. vivianemartinsdasilva@hotmail.com ${ }^{6}$ Doctorate in nursing. Professor, Department of Nursing, Universidade Federal do Ceará. CNPq Researcher. Fortaleza, CE, Brazil.. Fortaleza, CE, Brasil. marcos@ufc.br
} 


\section{INTRODUCTION}

Among the cardiovascular diseases, stroke stands out as one of the most prevalent and important causes of neurological deficits. Approximately $20 \%$ of patients with a stroke survive only a month after its occurrence; another $50 \%$ survive longer, but present considerable and permanent deficiencies, requiring care. The remaining $30 \%$ presented neurological deficits, permanently acquiring a certain degree of dependency ${ }^{(1)}$.

In addition to the large repercussions for the patient, his family and community, investments in prevention of this disease are crucial to avoid costs associated with hospitalization and rehabilitation ${ }^{(2)}$. However, according to what was observed, caring for someone with a stroke at home is becoming more common in the everyday life of families. Some challenges are emerging for professional nurses: how to meet the needs of these patients and how to promote their health.

According to research that involved care/home care, the maintenance of patients in the home is no longer a trend, it is a reality. Thus, understanding the process of care in the home makes it possible to identify some of the shortcomings and fragilities toward which nurses must direct their attention, to establish priorities and focus their work ${ }^{(3)}$.

To provide more directive care, it is important to know the characteristics and needs of the patient, adjusting behaviors to the reality encountered.

Therefore, the objective of this study was to know the profile of patients with a stroke in home treatment, regarding functional capacity, mental status and anthropometric analysis.

Research such as this may contribute to the improvement of nursing care, making it more skilled and oriented to the needs of the populations studied, since the majority of work addresses the care for elderly patients, without evaluating individual cases, such as stroke, which imply different repercussions.

\section{METHOD}

This was a descriptive, transversal study, conducted in patients with stroke who were monitored by the Home Care Assistance Program (HCAP) of three hospitals in Fortaleza/CE, in the period of January to April of 2010. The sample consisted of patients with a medical diagnosis of stroke who were older than 18 years of age. Those who, in addition to the stroke, had mental disorders, other neurological diseases, or were alcoholics or chemically dependent, were excluded. We selected the participant group by convenience, in a consecutive manner. Thus, we included all those monitored by the HCAP during the data collection period and who met the inclusion criteria, totaling 61 patients.

To collect data, we used a format established by means of bibliographical survey and subjected to the validation through the opinion of three nurse specialists in the care of patients with stroke or with dependent patients. This strategy was designed to evaluate face validity, and whether the construct responded to the research question. All the suggestions were adopted, and contributed to the refinement of the data collection instrument.

The following data were evaluated: gender, education, age, duration of illness, weight, height, body mass index (BMI), calf and arm circumference, leg length, subscapular skinfold, functional capacity and cognitive function.

To perform anthropometric measurements, an estimate of the weight and height, according to standardized formulas ${ }^{(4-5)}$ was made, that considered values of calf and arm circumference, leg length and subscapular skinfold. These equations presented important limitations, such as the high margin of error and the need for various body measurements. However, since more simplified and accurate equations have not been designed, we used these formulas ${ }^{(4-5)}$ that allowed for such calculations.

The body mass index was calculated with data on estimated weight and height, by the formula: weight $(\mathrm{kg}) /$ height $^{2}\left(\mathrm{~m}^{2}\right)$ results in $\mathrm{kg} / \mathrm{m}^{2}$. The classification of nutritional status ${ }^{(6-7)}$ was performed in accordance with the degree of underweight: grade I - mild underweight (BMI 17.0 to $18.49 \mathrm{~kg} / \mathrm{m}^{2}$ ), grade II - moderate underweight (BMI 16.0 to $\left.16.99 \mathrm{~kg} / \mathrm{m}^{2}\right)$, grade III - severe underweight (BMI <16.0), normal weight (BMI 18.5-24.9 kg/m²), overweight (BMI $25-29.9 \mathrm{~kg} / \mathrm{m}^{2}$ ), class I obesity (BMI 30.0$\left.34.9 \mathrm{~kg} / \mathrm{m}^{2}\right)$, class II obesity $\left(35.0-39.9 \mathrm{~kg} / \mathrm{m}^{2}\right)$ and class III obesity (BMI> $40.0 \mathrm{~kg} / \mathrm{m}^{2}$ )

To evaluate the functional capacity to perform basic activities of daily living (BADL), the Portuguese version of the Barthel Index was used, which measures the degree of assistance required by an individual on ten items about mobility and personal care. The activities were: selffeeding, self-bathing, filing or cutting one's toenails, dressing oneself, urinary sphincter control, bowel sphincter control, using the bathroom, lying down/getting up from bed or chair, climbing a flight of stairs, walking in a line ${ }^{(8)}$. These items were summed, for a total possible of 0-100 points. A total of 0-20 indicated total dependence; 21-60, severe dependence; 61-90, moderate dependence; 91-99, very slight dependence; and 100, independence ${ }^{(9)}$.

In order to assess the functional capacity of patients, the instrumental activities of daily living (IADL)
Evaluation of patients with stroke monitored by home care programs Oliveira ARS, Araujo TL, Costa AGS, Morais HCC Silva VM, Lopes MVO 
scale was used ${ }^{(10)}$, validated in Brazil ${ }^{(11)}$ with a population of elderly, which had been verified to have a nearly perfect intraclass index and significant confidence interval, both in reproducibility (0.89) and objectivity (0.80). The assessment consisted of questions such as the ability to use the telephone, and to: shop, prepare meals, complete domestic tasks, take medications, manage finances and travel. The Lawton Scale permits the health professional to establish how much an individual is independent in the exercise of certain functions or, conversely, needs help, through gradients whose extremes are total independence and total dependence ${ }^{(11)}$.

We used the Mini Mental State Examination (MMSE), validated in $\operatorname{Brazi}^{(12)}$, to assess cognitive status. The scale is simple to use and can be easily administered in 5-10 minutes. The exam consists of several questions grouped into seven categories, each of these designed with the objective of evaluating specific cognitive functions: orientation to time (5 points), orientation to place (5 points), registration of three words ( 3 points), attention and calculation (5 points), recall of three words ( 3 points), language ( 8 points) and visual constructive ability (1 point).

Data were collected by nurses and undergraduate students in the last semester of the nursing program, who had completed previous training that addressed the theoretical content of the research and application of the instrument, which was piloted with four patients who were excluded from the study. The results were compiled in an Excel spreadsheet, version 8.0, processed and analyzed using the software, Statistical Package for the Social Sciences (SPSS), version 15.0. For all tests, the adopted significance level was $5 \%(p<0.05)$.

Data analysis proceeded using a descriptive statistical approach, with the distribution of absolute and relative frequencies for categorical variables and means, standard deviation, median and percentiles for continuous variables. For quantitative tests, the Shapiro-Wilk and Kolmogorov-Smirnov tests were applied to verify the adhesion of the data to the normal distribution. When the $p$-value in these tests was less than 0.05 the distribution was not normal, therefore, the median values more adequately represented the population. When the distribution was normal or symmetric, the mean and median values were similar.

The study was approved by the Ethics Committee of the Universidade Federal do Ceará (Federal University of Ceará), under protocol number 310/09, and in its development, all of the ethical principles of human research were followed, in accordance with Resolution 196/96 of the National Health Council. All patients signed the Terms of Free and Informed Consent form, and in any case in which it was impossible for them to do so, it was signed by the family caregiver.

\section{RESULTS}

The majority of the participants were female (59\%), with a mean of 73.57 years ( \pm 15.54 ) of age; $50 \%$ had studied for a year. The variable, time of the last stroke, and the number of previous episodes had asymmetric distributions $(p<0.05)$. Thus, the median values found were two prior episodes, and the time was 17 months. Medication use was reported by $98.4 \%$ of participants, with a daily mean of 5.67 ( \pm 2.61$)$ medicines.

Table 1 shows the characteristics of the patients with stroke, according to sex, BMI classification, functional capacity and cognitive status.

Table 1 - Characteristics of patients with stroke according to sex, BMI classification, functional capacity and cognitive state - Fortaleza, CE, Brazil, 2010

\begin{tabular}{|c|c|c|}
\hline Variables & $\mathbf{N}$ & $\%$ \\
\hline \multicolumn{3}{|l|}{ Sex } \\
\hline Female & 36 & 59 \\
\hline Male & 25 & 41 \\
\hline \multicolumn{3}{|l|}{ BMI Classification $^{1}$} \\
\hline Severely underweight grade III & 28 & 45,9 \\
\hline Moderately underweight grade II & 4 & 6,6 \\
\hline Mildly underweight grade I & 7 & 11,5 \\
\hline Normal & 20 & 32,8 \\
\hline Overweight & 1 & 1,6 \\
\hline \multicolumn{3}{|l|}{ Barthel Classification } \\
\hline Total dependency & 45 & 73,8 \\
\hline Severe dependency & 13 & 21,3 \\
\hline Moderate dependency & 3 & 4,9 \\
\hline \multicolumn{3}{|l|}{ Lawton Classification } \\
\hline Total dependency & 49 & 80,3 \\
\hline Partial dependency & 12 & 19,7 \\
\hline \multicolumn{3}{|l|}{ MMSE Classification $^{2}$} \\
\hline Normal & 3 & 4,9 \\
\hline Altered & 58 & 95,1 \\
\hline
\end{tabular}

${ }^{1}$ BMI: Body Mass Index; ${ }^{2}$ MMSE: Mini Mental State Examination.

It should be noted that, of those evaluated: $85.2 \%$ were bedridden; $78.7 \%$ had difficulty speaking; $70.5 \%$ did not have any disease other than the stroke; $57.4 \%$ did not practice any physical activity; $36.1 \%$ had some kind of alteration in skin integrity and wore bandages; $32.8 \%$ had difficulty hearing; $11.5 \%$ had a tracheostomy; and, $9.8 \%$ made use of catheterization.

In Table 2, the measures of central tendency and dispersion related to the sociodemographic and clinical data of the patients with stroke are displayed.

In relation to the anthropometric data, $45.9 \%$ presented as severely underweight, and $32.8 \%$ with a normal BMI. The mean BMI was around $16.51( \pm 4.47) \mathrm{Kg} / \mathrm{m}^{2}$. In addition, $45.9 \%$ made use of enteral nutrition, $72.1 \%$ had difficulty chewing, and 59\%, difficulty swallowing.

The cognitive level proved to be quite altered, because $95.1 \%$ of the individuals achieved a MMSE score inferior to that equivalent for their level of schooling. As with other variables, this scale revealed an asymmetrical distribution ( $p<0.05$ ), both in general form and when assessing each item individually: temporal orientation, spatial 
orientation, registration of three words, attention and calculation, recall of three words, language and visual constructive ability.

Table 2 - Distribution of measures of central tendency and dispersion of sociodemographic and clinical data of patients with stroke - Fortaleza, CE, Brazil, 2010

\begin{tabular}{lrrrc}
\hline & Mean & DP $^{1}$ & Median & p-value $^{\mathbf{2}}$ \\
\hline Age (years) & 73,57 & 15,54 & 76,00 & 0,330 \\
Schooling (years) & 3,70 & 4,61 & 1,00 & 0,001 \\
Number of strokes & 2,19 & 1,45 & 2,00 & 0,003 \\
$\begin{array}{l}\text { Time of the last stroke } \\
\text { (months) }\end{array}$ & 34,83 & 40,88 & 17,00 & 0,000 \\
Number of medications & 5,67 & 2,61 & 5,00 & 0,286 \\
per day & 5,62 & 7,97 & 0,00 & 0,000 \\
MMSE & 40,13 & 14,45 & 37,64 & 0,406 \\
Estimated weight (kg) & 154,17 & 9,59 & 152,41 & 0,735 \\
Estimated height (cm) & 16,51 & 4,47 & 15,89 & 0,837 \\
Estimated BMI & 14,51 & 22,48 & 0,00 & 0,000 \\
Barthel Index & 7,82 & 2,24 & 7,00 & 0,000 \\
Lawton Scale & \multicolumn{3}{l}{}
\end{tabular}

The cognitive level proved to be quite altered, because $95.1 \%$ of the individuals achieved a MMSE score inferior to that equivalent for their level of schooling. As with other variables, this scale revealed an asymmetrical distribution $(p<0.05)$, both in general form and when assessing each item individually: temporal orientation, spatial orientation, registration of three words, attention and calculation, recall of three words, language and visual constructive ability.

Regarding the degree of dependency of the patients, 73.8\% presented total dependence for BADLs and $80.3 \%$ for IADL. The median of these variables $(p<0.05)$ was a total score of zero on the Barthel Index and a seven on the Lawton Scale, the lowest score possible to obtain in both scales. This same fact was repeated when each item of both scales was evaluated, showing that patients were totally dependent. Table 3 displays the BADL according to the Barthel Index for patients with stroke.

Table 3 - Distribution of BADL, according to the Barthel Index for patients with stroke - Fortaleza, CE, Brazil, 2010

\begin{tabular}{|c|c|c|}
\hline Barthel Index & $\mathbf{N}$ & $\%$ \\
\hline \multicolumn{3}{|l|}{ Feeding } \\
\hline Dependent & 43 & 70,5 \\
\hline Needs help & 12 & 19,7 \\
\hline Independent & 6 & 9,8 \\
\hline \multicolumn{3}{|l|}{ Capacity to dress oneself } \\
\hline Dependent & 45 & 73,8 \\
\hline Needs help & 15 & 24,6 \\
\hline Independent & 1 & 1,6 \\
\hline \multicolumn{3}{|l|}{ Bathing } \\
\hline Dependent & 57 & 93,4 \\
\hline Independent & 4 & 6,6 \\
\hline
\end{tabular}

...Continue
...Continuation

\begin{tabular}{|c|c|c|}
\hline Barthel Index & $\mathbf{N}$ & $\%$ \\
\hline \multicolumn{3}{|l|}{ Use of the bathroom } \\
\hline Dependent & 52 & 85,2 \\
\hline Needs help & 7 & 11,5 \\
\hline Independent & 2 & 3,3 \\
\hline \multicolumn{3}{|l|}{ Personal Care } \\
\hline Needs help & 54 & 88,5 \\
\hline Independent & 7 & 11,5 \\
\hline \multicolumn{3}{|l|}{ Urinary elimination } \\
\hline Incontinent & 44 & 72,1 \\
\hline Occasional accident & 7 & 11,5 \\
\hline Continence & 10 & 16,4 \\
\hline \multicolumn{3}{|l|}{ Intestinal elimination } \\
\hline Incontinent & 38 & 62,3 \\
\hline Occasional accident & 9 & 14,8 \\
\hline Continence & 14 & 23,0 \\
\hline \multicolumn{3}{|l|}{ Climbing stairs } \\
\hline Dependent & 57 & 93,4 \\
\hline Needs help & 4 & 6,6 \\
\hline \multicolumn{3}{|l|}{ Ambulation } \\
\hline Immobile & 49 & 80,3 \\
\hline Independent in wheelchair & 4 & 6,6 \\
\hline Minimal assistance & 7 & 11,5 \\
\hline Independent walking & 1 & 1,6 \\
\hline \multicolumn{3}{|c|}{ Goes from bed to chair and chair to bed } \\
\hline Unable & 42 & 68,9 \\
\hline Great help & 12 & 19,7 \\
\hline Little help & 4 & 6,6 \\
\hline Independent & 3 & 4,9 \\
\hline
\end{tabular}

When evaluating BADL individually, it was observed that the majority of patients could not perform each activity on their own, or needed the support of a caregiver to perform the task. The same happened when checking the IADL presented in Figure 1. We can see here the degree of incapacity evidenced by the Lawton Scale for patients with stroke.

\section{Lawton Scale}

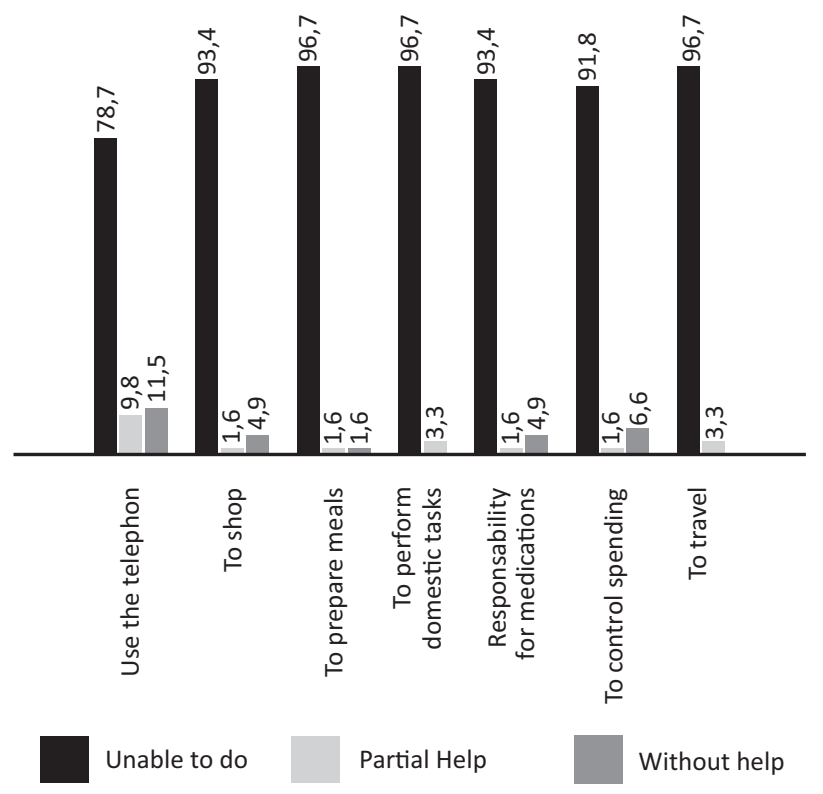

Figure 1 - Degree of inability to perform IADL, according to the Lawton Scale - Fortaleza, CE, Brazil, 2010
Evaluation of patients with stroke monitored by home care programs Oliveira ARS, Araujo TL, Costa AGS, Morais HCC Silva VM, Lopes MVO 
In regard to the caregiver, the majority were female (93.4\%), married $(52.5 \%)$ and a child of the patient with the stroke (50.8\%). In addition to the primary caregivers, $72.1 \%$ of the patients had a secondary caregiver to assist in the care, and $26.2 \%$ paid someone to assist in care. When it was needed, patients could count on the support of an eventual caregiver (36.1\%).

\section{DISCUSSION}

The current view of health care proposes that individuals with chronic disease care remain in the same environment in which they lived and became ill, therefore, in their home. Therefore, home care programs should be developed by multidisciplinary teams, based on each situation experienced ${ }^{(13)}$.

To know the profile of this patient enables more effective actions for the promotion, maintenance and rehabilitation of health. In this study, the profile of patients with stroke with regard to their functional capacity, cognitive and anthropometric analysis presented unfavorable results, characterizing those investigated as a vulnerable group.

In terms of functional capacity, $73.8 \%$ of participants manifested total dependence for BADL, and $80.3 \%$ for IADL. Incapacity is a dynamic and progressive process, resulting from chronic degenerative diseases and physiological changes associated with aging, which may acutely occur in stroke and hip fracture ${ }^{(14)}$. This is related to compromise of physical and mental activities, making it impossible to perform activities autonomously and independently ${ }^{(15)}$.

Lower scores for BADL and IADL are associated with the limitation of the individual's autonomy, reducing his quality of life and increasing the risk of dependence, institutionalization and premature death. Functional status is the most reliable parameter in establishing criteria of care ${ }^{(14)}$.

Among the elements of functional capacity investigated, a study emphasized that functional losses for IADL occur almost twice as much as for BADL; this may indicate that the IADL index is a sensitive marker of the degree of socialization of the person ${ }^{(14)}$.

Another study ${ }^{(16)}$ presented similar results, in which all patient care for those interviewed presented varying degrees of dependence for performing BADL. Patients ranged from those with total dependence to those with mild dependence, according to scores obtained by the Barthel Index and the reporting of caregivers. As for the instrumental activities, according to the scores obtained by the scale of Lawton, all had high levels of dependency.

One factor that may be associated with the presence of functional impairment is cognitive deficit, which is manifested in the aging process and related to inherent biological losses of age and the cultural level of the in- dividual. In populations with low levels of education, especially, it can link to the presence of functional incapacity in ADL performance ${ }^{(17)}$.

In this study, $95.1 \%$ of the participants obtained MMSE scores less than those equivalent for their level of education. A previous study that evaluated the association of cognitive decline and functional capacity identified that there was a high number of skills that older people with cognitive decline could not perform, leading to greater dependence and restricting autonomy ${ }^{(17)}$. It is noteworthy that functional incapacity can interfere with personal and collective development of the individual.

These data corroborate the need for health services to be prepared to identify such individuals, providing them with differentiated care that is based in the participation of different professionals from the health arena, either in the hospital or at home. A study ${ }^{(18)}$ conducted with elderly residents with stroke in long-term institutions, which identified high levels of functional and cognitive incapacity, emphasized that care that was not addressed in a systematic manner, and suggested greater efforts by multidisciplinary teams and better investments.

Another condition that merits attention was related to the nutritional status of the patients with stroke, who in this stage generally becomes more susceptible to unintentional weight loss. Moreover, a reduction in appetite may frequently occur, usually attributed to the onset of other chronic diseases, use of various medications, chewing and swallowing problems, depression and changes in mobility, with consequent functional dependence ${ }^{(19)}$.

In relationship to the demographic data, $45.9 \%$ were severely underweight, and $32.8 \%$ had a normal BMI; $72.1 \%$ had difficulty chewing, and $59 \%$ had difficulty swallowing. These data characterize the nutritional risk of the participants.

The use of estimated measurements for weight and height is a practice recommended for bedridden patients, with results similar to actual values. A study on elderly with cancer ${ }^{(20)}$ identified that to determine the nutritional status of those being evaluated, estimated measures differed from the parameters encountered with using actual values, but should be employed, because the ignorance of height and weight made the routine and nutritional assessment of the patient difficult.

A study presented results that the elderly with high nutritional risk were those who encountered the worst socioeconomic conditions; an association between nutritional risk and chronic diseases was also identified ${ }^{(21)}$.

In this situation the work of the caregiver becomes fundamental, collaborating with activities that encourage independence of the patient to feed himself. However, it also consolidates the overload of activities, because more time is needed to carry the procedure 
with the feeding of the patient, and the fact that one must observe one's family member languishing further contributes to caregiver stress.

In this context of functional dependence, home nursing care is evidenced as an alternative for care of individuals with stroke. This service is based on the guidance, information and support from specialized professionals, for the patients and caregivers, and these actions are highly dependent on family and informal support for their proper functioning. The caregiver is responsible for the continuity of care provided by the team, thus becoming a therapeutic element in the rehabilitation process ${ }^{(15)}$.

The activities developed by the caregivers related to the conditions of the patients. The more compromised his autonomy, the greater are the demands and complexity of activities performed by the caregiver. And therefore, the higher his workload with social, emotional and physical consequences ${ }^{(22)}$. It is a vital role of all health professionals, especially nurses, to guide and educate family caregivers to perform complex care.

The development of these strategies in health education should be able to enhance their knowledge of the subject, beginning from their reality, enabling them to see themselves as subjects of the caring process. This emphasizes the need for a multidisciplinary team to support the decisions of caregivers and to monitor the care process periodically.

It is emphasized that the priority nursing actions must be performed by those professionals and not delegated to the caregiver, even in the context of the household. In addition, all other actions should be supervised periodically.

Multidisciplinary teams, formed by a physician, nurse, physiotherapist, speech therapist, occupational therapist, among other professionals, must work together with the caregivers of patients with stroke, in order to reduce or alleviate the caregiver work burden, a common situation in the continuum of care for people with dependency. Thus, it is hoped that this would encourage the caregiver to adopt preventive practices in the pursuit of health promotion and disease prevention.

\section{REFERENCES}

1. Marques S, Rodrigues RAP, Kusumota L. Cerebrovascular accident in the aged: changes in family relations. Rev Latino Am Enferm. 2006;14(3):364-71.

2. Bocchi SCM, Angelo M. Interação cuidador familiar-pessoa com AVC: autonomia compartilhada. Ciênc Saúde Coletiva. 2005;10(3):729-38.

3. Perlini NMOG, Faro ACM. Cuidar de pessoa incapacitada por acidente vascular cerebral no domicílio: o fazer do cuidador familiar. Rev Esc Enferm USP. 2005; 39(2):154-63.

\section{CONCLUSION}

Sixty-one subjects monitored by home care programs were evaluated. The majority was female $(59 \%)$, elderly with a mean age of 73.57 years $( \pm 15.54)$, with low education, a mean of 3.7 years of study $( \pm 4.6)$, and a history of other episodes of stroke, and $50 \%$ presented two episodes in 17 months.

In terms of functional capacity, $73.8 \%$ presented total dependence for BADL and $80.3 \%$ for IADL, with the median indicating the minimum score in both scales. The cognitive level proved to be quite altered, because $95.1 \%$ had MMSE scores less than that equivalent for their level of education. Regarding anthropometric analysis, $45.9 \%$ were severely underweight and the average BMI was $16.51( \pm 4.47) \mathrm{kg} / \mathrm{m}^{2}$.

The profile permitted the classification of the group as vulnerable, a situation exacerbated by other risk conditions, such as tracheostomy, gastric feeding tube and urinary catherization, difficulty hearing, speaking, chewing, swallowing, and daily use of various medications. The results of this work permitted the expanding of knowledge about the principle limitations imposed by the stroke on the patient monitored at home with support of the ADLs. However, the study conducted herein was limited by methodological design, which did not include the monitoring of patients. The above results enabled to expand the knowledge about the main limitations imposed by the stroke to the patient cared at home with PAD support.

It is hoped that further studies could be conducted from the same perspective, investigating patients who did not have the help of professional home care programs, the reality of most of those who have suffered a stroke. The number of research studies in the area should be increased, and contributions to the work of the nurses with these totally dependent individuals who would be institutionalized, if they should not be given due attention.

4. Chumlea WC, Roche AF, Steinbaugh ML. Estimating stature from knee height for persons 60 to 90 years of age. J Am Geriatr Soc. 1985;33(2):116-20.

5. Chumlea WC, Guo S, Roche AF, Steinbaugh ML. Prediction of body weight for the nonambulatory elderly from anthropometry. J Am Diet Assoc. 1988;88(5):564-8.

6. Organización Mundial de la Salud (OMS). El estado físico: uso e interpretación de la antropometria. Informe de um Comité de Expertos de la OMS. Ginebra; 1995.
Evaluation of patients with stroke monitored by home care programs Oliveira ARS, Araujo TL, Costa AGS, Morais HCC Silva VM, Lopes MVO 
7. World Health Organization (WHO). Obesity: preventing and managing the global epidemic. Report of a WHO Consultation. Geneva; 1998.

8. Mahoney FI, Barthel DW. Functional evaluation: the Barthel Index. Md State Med J. 1965;14:61-5.

9. Azeredo Z, Matos E. Grau de dependência em doentes que sofreram AVC. Rev Facul Med Lisboa. 2003;8(4): 199-204.

10. Lawton MP, Brody EM. Assessment of older people: selfmaintaining and instrumental activities of daily living. Gerontologist. 1969;9(3):179-85.

11. Santos RL, Virtuoso Júnior JS. Confiabilidade da versão brasileira da escala de atividades instrumentais da vida diária. Rev Bras Promoção Saúde [Internet]. 2008 [citado 2012 jul. 22];21(4): 290-6. Disponível em: http://ojs.unifor.br/index. php/RBPS/article/view/575

12. Bertolucci PH, Brucki SM, Campacci SR, Juliano Y. The MiniMental State Examination in a general population: impact of education status. Arq Neuropsiquiatr. 1994;52(1):1-7.

13. Albuquerque ABB, Bosi MLM. Visita domiciliar no âmbito da estratégia de saúde da família: percepções de usuários no município de Fortaleza, Ceará, Brasil. Cad Saúde Pública. 2009;25(5):1103-12.

14. Sthal HC, Berti HW, Palhares VC. Grau de dependência de idosos hospitalizados para realização das atividades básicas da vida diária. Texto Contexto Enferm. 2011;20(1):59-67.

15. Gratão ACM, Talmelli LFS, Figueiredo LC, Rosset I, Freitas CP, Rodrigues RAP. Functional dependency of older individuals and caregiver burden. Rev Esc Enferm USP [Internet]. 2013 [cited 2013 Mar 16];47(1):137-44. Available from:
16. http://www.scielo.br/pdf/reeusp/v47n1/en_a17v47n1.pdf

17. Oliveira ARS, Costa AGS, Chaves DBR, Alves FEC, Moreira RP, Araujo TL. Avaliação da capacidade funcional de idosos com acidente vascular encefálico. Rev Enferm UFPE on line [Internet]. 2011 [citado 2012 jul. 19];5(3):748-56. Disponível em: http://www.revista.ufpe.br/revistaenfermagem/index. php/revista/article/view/1654

18. Ferreira PCS, Tavares DMS, Rodrigues RAP. Sociodemographic characteristics, functional status and morbidity among older adults with and without cognitive decline. Acta Paul Enferm. 2011;24(1): 29-35.

19. Cowman S, Royston M, Hickey A, Horgan F, McGee H, O'Neill $D$. Stroke and nursing home care: a national survey of nursing homes. BMC Geriatr. 2010;10:4.

20. Parahyba MI, Veras R, Melzer D. Disability among elderly women in Brazil. Rev Saúde Pública. 2005;39(3):383-91.

21. Dock-Nascimento DB, Aguilar-Nascimento JE, Costa HCBAL, Vale HV, Gava MM. Precisão de métodos de estimativa do peso e altura na avaliação do estado nutricional de pacientes com câncer. Rev Bras Nutr Clin. 2006;21(2):111-6.

22. Alvarenga MRM, Oliveira MAC, Faccenda O, Amendola F. Evaluation of the nutritional risk in elderly assisted by Family Health Teams. Rev Esc Enferm USP [Internet]. 2011 [cited 2012 July 25];44(4):1046-51. Available from:

23. http://www.scielo.br/pdf/reeusp/v44n4/en_27.pdf

24. Morais HCC, Soares AMG, Oliveira ARS, Carvalho CML, Silva MJ, Araujo TL. Burden and modifications in life from the perspective of caregivers for patients after stroke. Rev Latino Am Enferm. 2012;20(5): 944-53. 